\title{
Distribution and Habitat Diversity of Subterranean Amphipods in the Rocky Mountains of Colorado, U.S.A.
}

\author{
James V. Ward* \\ and John R. Holsinger**
}

\begin{abstract}
SUMMARY
Subterranean amphipods have been collected from 35 locations on the eastern and western slopes of the Continental Divide in Colorado. All belong to the exclusively subterranean genus Stygobromus. Five species have been identified, two of which are undescribed. Specimens have been collected from (a) the hyporheic zone of rivers, (b) interrupted streams, (c) springs, and (d) seeps at elevations from 1597-2134 m a.s.l. Stygobromus occurs in several habitat types in interrupted drainage basins including sources, seeps, and isolated pools containing leaf detritus. All habitats contained waters which were cool to cold with dissolved oxygen values ranging from 4.3 $\mathrm{ppm}$ to fully saturated. Most waters exhibited soft or medium hardness, although one spring containing an undescribed species of Stygobromus had very hard waters $\left(203 \mathrm{ppm}\right.$ bound $\mathrm{CO}_{2}$ ) and was mildly saline ( $913 \mathrm{mg} / 1 \mathrm{TDS})$. There is evidence that the subterranean amphipods are phreatobites which, only under special conditions, establish relatively permanent populations in epigean habitats. Although little is known regarding ecology, zoogeography, or even taxonomy of the subterranean fauna of this region, stygobromid amphipods from the Cordilleran of western North America are apparently represented by fewer well differentiated species per unit area than their congeners from the geologically older Appalachian region of eastern North America where numerous species are found in caves.
\end{abstract}

\section{INTRODUCTION}

The great diversity of aquatic habitats in the western United States is associated with dramatic shifts in climate, geochemistry, and topography, often over relatively short distances (Pennak, 1958). Stygobromus, the only subterranean amphipod genus occurring in the far western United States, has been previously reported from caves, lava tubes, wells, springs, and the profundal zone of a Pleistocene relict lake (Holsinger, 1974). Holsinger emphasized the highly insular distribution of subterranean species and predicted the discovery of a new species of Stygobromus in the rugged mountainous country of this region.

Recent descriptions of three Cordilleran species (Ward, 1977) provided the first records of subterranean amphipods in Colorado and brought to 21

* Department of Zoology and Entomology Colorado State University Fort Collins, Colorado 80523 U.S.A. .

** Department of Biological Sciences Old Dominion University Norfolk, Virginia 23508 U.S.A. . 
the total number of western species. Further studies in Colorado have resulted in the discovery of two additional species, which will be described elsewhere (Holsinger \& Ward, in preparation), and extensions in range and habitat type for the recently described $S$. holsingeri Ward.

It is the purpose of this paper (1) to describe the recorded distribution of subterranean amphipods in Colorado, and (2) to describe the variety of habitats, some of which are somewhat unusual, which the various species occupy.

\section{GEOGRAPHICAL DISTRIBUTION}

Since 1974, numerous stygobromid amphipods have been collected from three general areas of Colorado (Fig. 1). Stygobromus coloradensis Ward and $S$. pennaki Ward, originally reported from the North Fork of the South Platte River (Ward, 1977), have also been found to occur sympatrically in the South Platte River proper.

Sixteen specimens of Stygobromus (undescribed species B) were collected from a saline spring at $19851 \mathrm{~m}$ elevation in an area of sedimentary rock deposited by ancient Lake Uinta. This location in the Upper Colorado River Basin is the only known occurrence of subterranean amphipods west of the Continental Divide in Colorado.

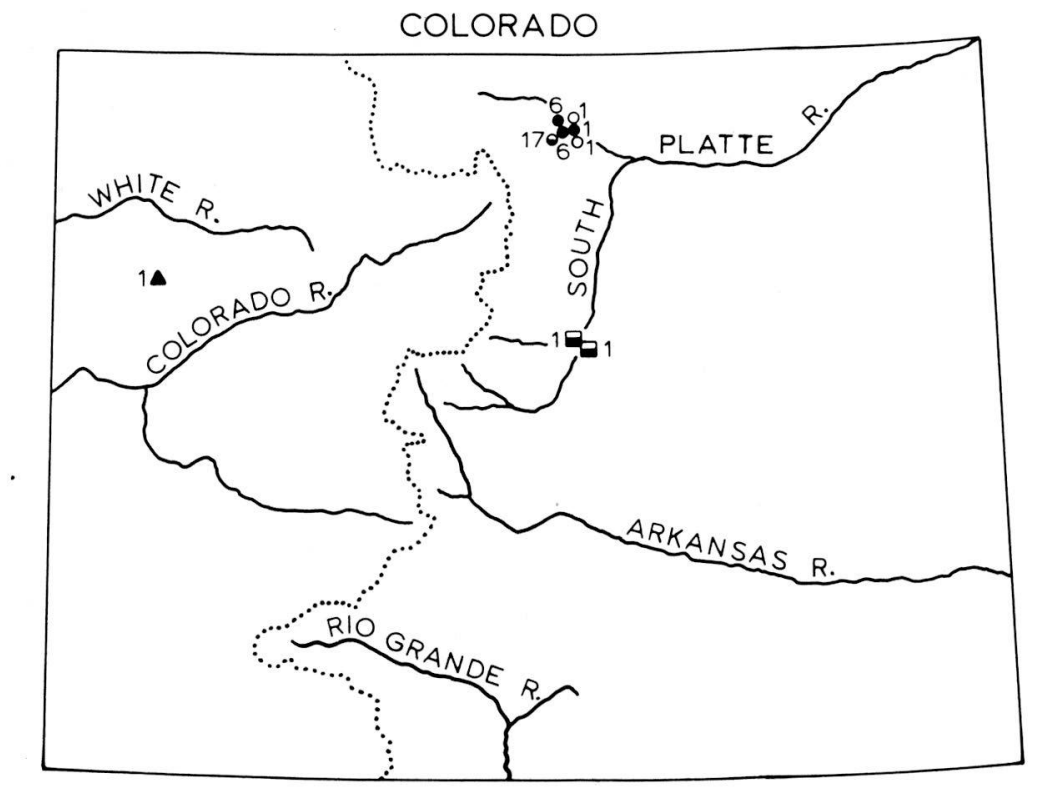

Fig. 1. Distribution of Stygobromus in Colorado, U.S.A. Species are indicated as follows: $S$. coloradensis, $\square$ S. pennaki, $\bullet S$. holsingeri, $\bigcirc$ undescribed sp. A, $\Delta$ undescribed sp. B. Arabic numerals indicate the number of locations from which specimens have been collected. Dotted line is the Continental Divide. 
Well over 600 specimens of two species of Stygobromus have been collected from several habitat types at numerous locations (1597-2134 $\mathrm{m}$ a.s.l.) in the area surrounding Horsetooth Reservoir in northern Colorado (Fig. 2). The seep on the hogback ridge on the east side of the reservoir is the typelocality of $S$. holsingeri, which has subsequently been found in relatively inaccessible canyons on the next east-facing slope (Devil Gulch and Soldier Canyon), and in an unnamed drainage system on the east-facing slope of

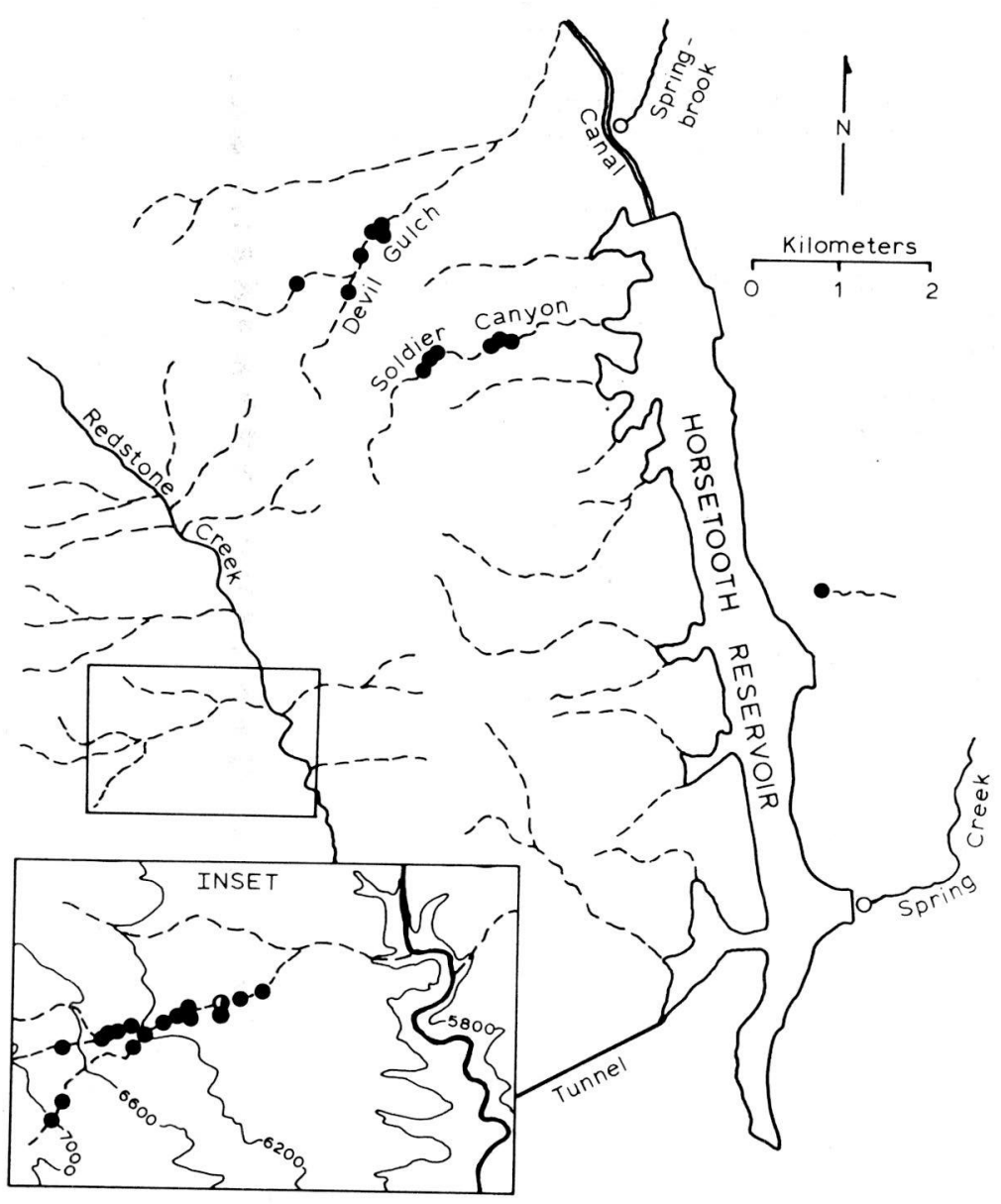

Fig. 2. Distribution of Stygobromus in springs, seeps, and interrupted stream systems (dashed lines) in the civinity of Horsetooth Reservoir in northern Colorado. Symbols as in figure 1. Contour lines, from a U.S. Geological Survey map, are shown in the inset for 5800 feet $(1768 \mathrm{~m}), 6200$ feet $(1890 \mathrm{~m}), 6600$ feet $(2012 \mathrm{~m})$, and 7000 feet $(2134 \mathrm{~m})$ elevations. 
Redstone Creek (Fig. 2 inset). Undescribed species A occurs sympatrically with $S$. holsingeri at a site in the unnamed drainage basin. Conversely, while over 60 specimens of Stygobromus have been collected from springs at the north and south ends of Horsetooth Reservoir, all individuals have been identified as undescribed species A. A one-year study of the profundal benthos of Horsetooth Reservoir (Edmonds \& Ward, 1979) failed to yield amphipods.

\section{HABITAT DIVERSITY}

River hyporheic. Initial collections of $S$. coloradensis and $S$. pennaki were from the North Fork just above the confluence of the South Platte River (Ward, 1977). Additional specimens have been taken from that location, and both species have since been collected in the South Platte River above the confluence. The two foothills locations (1855 $\mathrm{m}$ a.s.l.) provide somewhat different environmental conditions despite their contiguity (Ward, 1976). North Fork water is softer ( 15 vs 36 ppm bound $\mathrm{CO}_{2}$ ), with lower values of total dissolved solids (67.6 vs $191.5 \mathrm{mg} / 1)$. The North Fork has well-developed riparian vegetation with large inputs of allochthonous detritus, whereas the South Platte River is primarily autotrophic with large standing crops of epilithic algae. However, thermal conditions were similar at both locations and dissolved oxygen values were always near saturation. Stygobromids were collected immediately upstream from small islands at both river locations. Although there was rubble on the substrate surface, the amphipods occur in the interstices of granitic sand and gravel of the hyporheic zone (Table 1). In April of 1977, the stygobromid density in the top $30 \mathrm{~cm}$ of substrate was estimated to be 511 amphipods $/ \mathrm{m}^{2}$ at the South Platte River location and $436 / \mathrm{m}^{2}$ for the North Fork. Although amphipods (e.g., Niphargus) are widespread in hyporheic habitats in Europe, no other subterranean amphipods have been reported from the hyporheic zone in North America.

Saline spring. In May 1977, 16 specimens of an undescribed species of Stygobromus were collected from a small saline spring which emerges from the base of a hill in western Colorado (Fig. 1). Water temperature at the time of collection was $8^{\circ} \mathrm{C}$; the water was very hard $\left(203 \mathrm{ppm}\right.$ bound $\left.\mathrm{CO}_{2}\right)$, mildly saline (913 mg/1 TDS), and athalassohaline. Subterranean amphipods have not been previously reported from saline springs in North America. The amphipods are apparently phreatobites since specimens were restricted to the source and, in fact, were found only by digging deep into the source while holding a net downstream. Substrate consisted of flat rubble and gravel chips composed of shale, marlstone, and sandstone.

Northern Colorado habitats. Stygobromids have been collected from springbrook, seep, and interrupted stream habitats in northern Colorado (Table 1, Fig. 2). The seep to the east of Horsetooth Reservoir is completely isolated from other surface waters. It flows only periodically and then for only a few meters. The bedrock is sandstone with some conglomerate. The am- 
Table 1. Habitat type and dominant substrate for Stygobromus in Colorado. (See text for physicochemical habitat characteristics).

\begin{tabular}{|c|c|c|c|c|c|}
\hline \multirow[b]{2}{*}{ Species } & \multirow{2}{*}{$\begin{array}{l}\text { General } \\
\text { habitat }\end{array}$} & \multicolumn{3}{|c|}{ Specific Habitat* } & $\begin{array}{l}\text { Dominant } \\
\text { Substrate** }\end{array}$ \\
\hline & & Pool & Source & Hyporheic & C D M R G S \\
\hline coloradensis & rivers & - & - & 2 & $\mathrm{Xx}$ \\
\hline pennaki & rivers & - & - & 2 & $\mathrm{x} x$ \\
\hline \multirow[t]{2}{*}{ holsingeri } & seep & - & 1 & - & $\mathrm{x}$ \\
\hline & streams & 14 & 15 & - & $\mathrm{X} \times \mathrm{X} \times \mathrm{X} \times$ \\
\hline \multirow[t]{2}{*}{ undescr.sp.A. } & $\begin{array}{l}\text { springbrooks } \\
\text { interrupted }\end{array}$ & - & 2 & - & $\mathrm{X} \times \mathrm{X}$ \\
\hline & stream & - & 1 & - & $\mathrm{X} \times \mathrm{X}$ \\
\hline undescr.sp.B. & saline spring & - & 1 & - & $\mathrm{XX}$ \\
\hline
\end{tabular}

* Numerals indicate number of locations

** $\mathrm{C}=$ conifer needles

$\mathrm{D}=$ deciduous leaves

$\mathbf{M}=$ mud and silt

$\mathrm{R}=$ rubble

$\mathrm{G}=$ gravel

$\mathrm{S}=$ sand

phipods were associated with masses of pine needles and cow pats at the source. The source temperature was $8^{\circ} \mathrm{C}$; pH was 6.0 .

Stygpbromids were collected from springbrooks at apposite ends of Horsetooth Reservoir (Fig. 2). An undescribed species was taken in watercress (Rorippa nasturtium-aquaticum) from the source of Spring Creek. Water temperature was $8^{\circ} \mathrm{C}$; ph was 7.3 . The substrate consists primarily of sand and gravel. During a one-year study of the springbrook north of Horsetooth Reservoir not a single stygobromid amphipod was collected, despite monthly sampling of several habitats near the source. Over two years after the completion of the study, 14 specimens of an undescribed species of Stygobromus were collected. Subsequent collecting has resulted in 40 additional specimens. All were taken under small rocks just at the source. A sampling station less than a meter away failed to yield a single amphipod during the year of study. Detailed data on physicochemical conditions, macrophytes, macroinvertebrates, and epilithic algae are presented in Ward and Dufford, 1979. Source temperatures varied from $8-10^{\circ} \mathrm{C}$ throughout the year. Annual means were as follows: $\mathrm{pH}, 7.7$; bound $\mathrm{CO}_{2}, 29.5 \mathrm{ppm}$; TDS, $116 \mathrm{mg} / 1$. The bedrock is primarily sandstone with some limestone.

Subterranean amphipods were collected from 29 locations in three interrupted drainage systems west of Horsetooth Reservoir. The most intensive work was conducted on the unnamed drainage across a small chain of mountains (Fig. 2 inset) where Stygobromus was collected from 17 locations (1817- 
$2134 \mathrm{~m}$ a.s.l.). Specimens were taken during all seasons, but were most abundant in late April and early May, the time of greatest surface flow. Even then the length of dry streambed exceeded that carrying surface water, although this varied greatly at different locations. Schist and gneiss compose the bedrock above about $1800 \mathrm{~m}$ elevation; a fine-grained red sandstone occurs in lower reaches.

While the following physical and chemical data apply specifically to the unnamed drainage confluent to Redstone Creek, all interrupted streams were generally similar. Water temperatures ranged from $5-9^{\circ} \mathrm{C}$ at locations from which Stygobromus was collected during April-May. Bound $\mathrm{CO}_{2}$ ranged from $16.5 \mathrm{ppm}$ at upper elevations to around $40 \mathrm{ppm}$ at downstream sites. Dissolved oxygen varied from 4.3 to $7.4 \mathrm{ppm}$. The $\mathrm{pH}$ was near neutrality at all locations. Total dissolved solids ranged from $50.4 \mathrm{mg} / 1$ at an upper site to 96.4 at a downstream location. Near the mouth, the temperature was $9.5^{\circ} \mathrm{C}$; pH was 7.6; bound $\mathrm{CO}_{2}$ was $66 \mathrm{ppm}$; TDS was $167.4 \mathrm{mg} / 1$. However, no subterranean amphipods were found in the lower reaches of sandstone beelrock despite otherwise seemingly suitable conditions. It is thought that the fine grain of the sandstone precludes interstitial forms since Stygobromus occurs at locations which have coarse-grained sedimentary rocks or have conglomerates mixed with sandstone.

Stygobromus occupied several habitat types in the interrupted drainage basins. Some sites were similar to rheocrene sources since water emerged with a good current and the substrate was composed of rubble and gravel. At other locations, the water seeped out more slowly and there was a finer substrate. Some of the latter formed pools which filled with conifer needles or deciduous leaves, forming the "biotope hypotelminorhéique" of Meŝtrov (1962). Some locations were isolated leaf-filled pools scarcely $30 \mathrm{~cm}$ across which, despite their apparently stagnant condition, had low but adequate dissolved oxygen concentration. Subterranean amphipods were not collected from sections in which surface flow continued more than a few meters.

\section{CONCLUSIONS}

By contrasting Colorado habitats from which Stygobromus have been collected with those from which subterranean amphipods are absent, the following generalizations are cautiously presented. It should be emphasized that Colorado has only recently been explored for subterranean amphipods, and many geographical areas have yet to be investigated.

It is thought that the Stygobromus collected in Colorado are phreatic forms which are accidentals in epigean habitats. Even the hyporheic habitat is considered to be part of the phreatic zone by some authors (e.g., Chappius, 1950). The restriction of Stygobromus to the source region of springbrooks supports this viewpoint. Only under special conditions, such as occur in certain interrupted streams, will relatively permanent populations be established in surface waters. If surface waters persist long enough for the establishment of a normal aquatic fauna, Stygobromus will be excluded or restricted to the 
immediate area of egress. If the bedrock is too close to the surface, or if the substrate is too fine, Stygobromus will be absent.

Certain orgnaisms commonly occur in samples containing Stygobromus. If ephemeropterans do occur, they are nearly always Baetis. The lumbricid Eiseniell tetraedra is a common associate, as are several tipulids and certain chironomids. Hesperophylax and hydroptilid trichopterans are also common associates, as are dytiscid and hydrophilid coleopterans. If plecopterans are present, they are usually nemourids, although two carnivorous stoneflies have been collected from Stygobromus habitats. Alloperla was common in the hyporheic zone of the North Fork and South Platte Rivers, but most specimens were early instars which are primarily detritivores. Mature nymphs of Isoperla patricia occurred deep within the saline spring source, an unusual habitat for a medium-sized carnivorous stonefly. Epigean amphipods are rarely present in habitats containing Stygobromus. Although Hyalella azteca was present in the springbrook north of Hossetooth Reservoir (Ward \& Dufford, 1979), not a single specimen was collected from the sampling substation near the source from which the undescribed Stygobromus was collected.

Stygobromid amphipods from the Cordilleran region of western North America are apparently represented by fewer well differentiated species per unit area than their congeners from the geologically older Appalachian region of eastern North America where numerous species are found in caves (see Holsinger, 1978). To date, the relatively few wet caves in Colorado have not been examined for aquatic organisms.

In Europe and the eastern United States, the subterranean fauna has been relatively well studied. In the western United States, however, many basic questions relating to predator-prey and competitive interactions, seasonal and diurnal migrations, zoogeography and phylogeny remain unanswered and provide fertile areas for future research.

\section{ACKNOWLEDGMENTS}

The authors wish to thank Dr. R.W. Pennak, University of Colorado, for critically reviewing the manuscript and Dr. G. Magniez, University of Dijon, for assistance with the French résumé.

\section{RÉSUMÉ}

Des Amphipodes souterrains ont été collectés en 35 endroits différents, répartis sur les versants Est et Ouest des Montagnes Rocheuses, au Colorado. Tous appartiennent au genre exclusivement souterrain Stygobromus. Sur les cinq espèces capturées, deux font l'objet d'une description. Les spécimens ont des origines variées: milieu interstitiel hyporhéique des rivières, résurgences de ruisseaux, sources et suintements temporaires, situés à des altitudes comprises entre 1597 et 2134 mètres. On trouve les Stygobromus dans plusieurs biotopes différents dans les bassins à écoulement interrompu: sources, ruissellements, mares isolées contenant des débris de feuilles. Dans tous les biotopes, les eaux sont fraîches ou froides et la teneur eu oxygène varie de 4,3 p.p.m. à la saturation totale. La dureté est moyenne ou faible pour la plupart des eaux, mais une source d'eau très dure (203 p.p.m. de $\mathrm{CO}_{2}$ lié) et légèrement saline $(913 \mathrm{mg} / 1$ de substances dissoutes) contient une espece non décrite de Stygobromus. Il paraît évident que les Amphipodes souterrains sont des phréatobies qui n'établissent des populations relativement permanentes dans 
les biotopes épigés que dans des conditions particulières. Bien que l'écologie, la zoogéographie et même la taxonomie de la faune souterraine de cette région soient encore peu connues, les Amphipodes Stygobromes de la Cordillère occidentale de l'Amérique du Nord semblent représentés, par unité de surface, par un moins grand nombre d'espèces que leurs congénères des Appalaches, à l'Est de l'Amérique du Nord, région géologiquement plus ancienne, où l'on trouve de nombreuses espèces dans les grottes.

\section{LITERATURE}

CHAPPIUS P.A. 1950. La récolte de la faune souterraine. Notes Biospéol. 5:7-35.

EDMONDS J.S., and J.V. WARD. 1979. Profundal benthos of a multibasin foothills reservoir in Colorado, U.S.A. Hydrobiologia 63:199-208.

HOLSINGER J.R. 1974. Systematics of the subterranean amphipod genus Stygobromus (Gammaridae), Part I: Species of the Western United States. Smithsonian Contrib. Zool. No. 160:1-63.

HOLSINGER J.R. 1978. Systematics of the subterranean amphipod genus Stygobromus (Crangonyctidae), Part II: Species of the Eastern United States. Smithsonian Contrib. Zool. No. 266:1-144.

MEŚTROV M. 1962. Un nouveau mileau aquatique souterrain: Le Biotope hypotelminorhéique. Comptes Rendus 254:2677-2679.

PENNAK R.W. 1958. Some problems of freshwater invertebrate distribution in the Westerti States, in: Zoogeography, HUBBS C.L., Ed., Amer. Assoc. Adv. Sci., Washington, D.C.: $223-230$.

WARD J.V. 1976. Comparative limnology of differentially regulated sections of a Colorado mountain river. Arch. Hydrobiol. 78:319-342.

WARD J.V. 1977. First records of subterranean amphipods from Colorado with descriptions of three new species of Stygobromus (Crangonyctidae). Trans. Am. Microsc. Soc. 96:452466.

WARD J.V., and R.G. DUFFORD. 1979. Longitudinal and seasonal distribution of macroinvertebrates and epilithic algae in a Colorado springbrookpond system. Arch. Hydrobiol. 86:284-321. 